Journal of

Aslan Concrete Federation

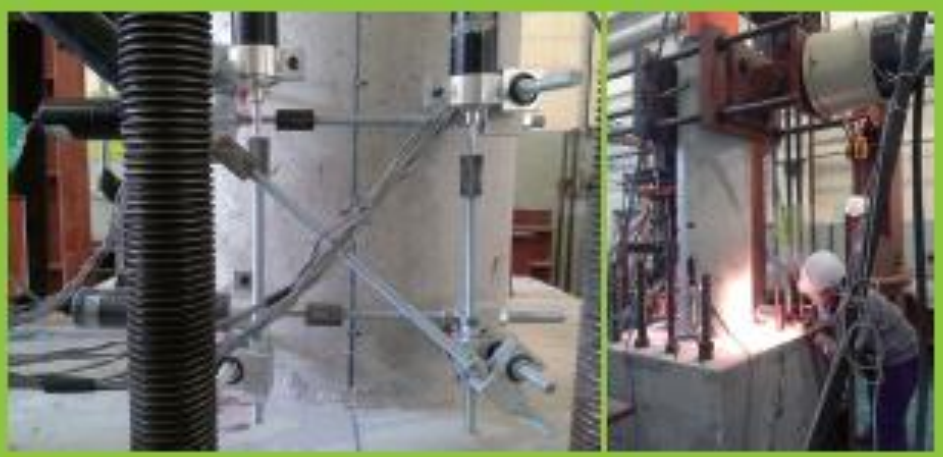

Analytical model for axial stress-strain behavior of welded reinforcement grid confined concrete: columns $1-10$

Tavio and B. Kusuma

Mechanical properties of kenaf fiber reinforced concrete with different fiber content and fiber length $11-21$

Tran Fook Lam and Jamaludin Mohamad Yatim

Flexural performance evaluation of composite steel deck oneway slab system with SFRC $22-27$

Geonho Hong

Laboratury accelerated and outdoor durability testing of concrete with supplementary cementitious materials $28-36$

Eisuke Nakamura and Hiroshi Watanabe

Ductile fiber wrapping for seismic retrofit of reinforced concrete columns $37-46$

Donguk Choi, S. Vachirapanyakun, S.Y. Kim, and S.S. Ha

Strength and ductility of external steel collared concrete columns under compressive loading 47-56 Tavio, P. Pudjisuryadi, and P.Suprobo

Effect of a small addition of highly expansive slag on volume stability of cement matrix materiat $57-63$ Wei Chien Wang, Chih Chien Liu, and Chau Lee

Bi-annual technical journal

Published by Asian Concrete Federation [ACF) 


\section{Journal of \\ Asian Concrete \\ Federation}

\section{ACF Journal}

\begin{tabular}{|c|c|c|}
\hline Editor-In-Chief & Donguk Choi & Hankyong National University, Korea \\
\hline \multirow[t]{2}{*}{ Vice Editor-In-Chiefs } & Vijay Kulkami & RMCMA, India \\
\hline & Myoungsu Shin & Ulsan National Institute of Science and Technology, Korea \\
\hline \multirow[t]{17}{*}{ Editorial Board } & Gyorgy L. Balazs & Budapest University of Technology and Economics, Hungary \\
\hline & Yin Wen Chan & National Taiwan University, Taiwan \\
\hline & Nguyen Van Chanh & Ho Chi Minh City University of Technology, Vietnam \\
\hline & Iswandi Imran & Institut Teknologi Bandung, Indonesia \\
\hline & Jang-Ho Jay Kim & Yonsei University, Korea \\
\hline & H. K. Lee & Korea Advanced Institute of Science and Technology, Korea \\
\hline & MyungKwan Lim & Hankyong National University, Korea \\
\hline & Haraid S. Mueller & Karlsruhe Institute of Technology, Germany \\
\hline & Takafumi Noguchi & The University of Tokyo, Japan \\
\hline & Jan Olek & Purdue University, U.S.A. \\
\hline & Hong-Gun Park & Seoul National University, Korea \\
\hline & Gianluca Ranzi & The University of Sydney, Australia \\
\hline & Kiang Hwee Tan & National University of Singapore, Singapore \\
\hline & Somnuk Tangtermsirikul & Sinndhorn Intemational Institute of Technology, Thailand \\
\hline & James Wight & University of Michigan, U.S.A. \\
\hline & Duinkherjav Yagaanbuyant & Mongolian University of Science and Technology, Mongolia \\
\hline & Jung Heum Yeon & Gachon University, Korea \\
\hline
\end{tabular}

Published by Asian Concrete Federation (ACF)

http://www.asianconcretefederation.org

Editorial office:

School of Architectural Engineering and Architecture,

Hankyong National University

327 Chungang-ro, Anseong-si, Gyeonggi-do, 456-749, Republic of Korea

Phone: $+82-31-670-5272$

Fax: $+82-31-670-5279$

(8) Asian Concrete Federation

ISSN 2465-7964

eISSN 2465-7972

Cover photo: column tests by Donguk Choi 


\section{Journal of Asian Concrete Federation}

Vol. 1, No. 1, September 2015

Analytical model for axial stress-strain behavior of welded reinforcement grid confined concrete columns 1-10

by Tavio and B. Kusuma

Mechanical properties of kenaf fiber reinforced concrete with different fiber content and fiber length 11-21

by Tian Fook Lam and Jamaludin Mohamad Yatim

Flexural performance evaluation of composite steel deck one-way slab system with SFRC 22-27

by Geonho Hong

Laboratory accelerated and outdoor durability testing of concrete with supplementary cementitious materials 28-36

by Eisuke Nakamura and Hiroshi Watanabe

Ductile fiber wrapping for seismic retrofit of reinforced concrete columns $37-46$ by Donguk Choi, S. Vachirapanyakun, S.-Y. Kim, and S.-S. Ha

Strength and ductility of external steel collared concrete columns under compressive loading $47-56$

by Tavio, P. Pudjisuryadi, and P. Suprobo

Effect of a small addition of highly expansive slag on volume stability of cement matrix material $57-63$

by Wei Chien Wang, Chih Chien Liu, and Chau Lee

Aims and scope

Joumal of Asian Concrete Federabion (ACF Journal) provides an intemational forum to disseminate and exchange most recent technical information of concrefe materials and structures among engineers, researchers, and educators in Asia as well as around the worid.

ACF Joumal is regularly published under the auspice of Asian Concrete Federation. The Editorial Board of ACF Joumal consists of eminent scholars from ACF member countries as well as top-class scholars invited from all over the wond. Article topics include, but are not limited to:

1. Concrete structures:

2. Concrete materials and technologies;

3. Maintenance, monitoring, repair, and strengthening:

4. Sustainability,

5. Construction and engineering; and

6. Recent research and related topics

Discussions

Discussion on any article published in eartier issues of ACF Journal is welcome for possible publication with the Author's Closure.

Copyright transfer agreement Completion of a signed Copynight Transfer Agreement wiV be requived upon acceptance of the manuscript. No article can be putished unless a signed publicaion agreement is provided, which serves as a transfer of copyright from author to publisher. ACF Joumal does not advocate open access policies for copynighted articles. It is the author's responsibility to obtain witten permission to reproduce materiais that has appeared in another publication. 


\title{
Strength and ductility of external steel collared concrete columns under compressive loading
}

\author{
Tavio*; P. Pudjisuryadi and P. Suprobo \\ (Received: February 16, 2015; Accepted: September 1, 2015; Published online: September 30, 2015)
}

\begin{abstract}
Many studies have revealed that one way to improve the performance of concrete columns is by providing confinement. Recently, external confining methods have drawn interest of researchers due to its main advantage for retrofitting purpose of existing members. Steel jacketing methods have long been proposed by several studies for externally retrofitting circular concrete columns. On the other hand, the lack of research has been found in addressing its impacts on the rectangular and square concrete sections. This paper discusses the experimental results and behavior of concrete columns under concentric static axial loading. Nine column specimens were cast and tested to observe their behaviors. A control specimen (CS01) was cast without confinement, while another one (CS03a) was provided with internal stirrups to conform the seismic requirements of building code. The other seven specimens were retrofitted with a set of L-shaped steel collars. Specimens S04a and S04b have both traditional internal stirrups and external L-shaped steel collars. These spesimens were intended to simulate the retrofitting work of existing RC columns. The other specimens (S04, S04c, S04d, S04e, and S04f) used various collar configurations to examine the impact of this new retrofitting method. The results have shown significant improvement in both strength and ductility of square concrete column confined externally by L-shaped steel collars.
\end{abstract}

Keywords: compressive strength, ductility, external confinement, retrofit, square concrete columns, steel collars.

\section{Introduction}

Concrete under compression suffers tensile stress or strain due to lateral expansion [1-2]. One of the important issues is the brittle failure of concrete due to this axial compressive loading. When an unconfined concrete member is in progressive axial compression, it will fail in a brittle manner. However, this condition will not occur when a concrete member is well confined. The higher the confining degree is provided, the later the concrete member will fail beyond the post-peak response. This improved behavior is certainly needed to significantly delay the failure of structural components during the severe earthquake strike. The ductile behavior is strictly required by the latest building codes which have implemented the modern seismic

Corresponding author Tavio is a Professor of Department of Civil Engineering, Sepuluh Nopember Institute of Technology (ITS), Surabaya, Indonesia.

P. Pudjisuryadi is a Ph.D. candidate of Department of Civil Engineering, Sepuluh Nopember Institute of Technology (ITS), Surabaya, Indonesia.

P. Suprobo is a Professor of Department of Civil Engineering, Sepuluh Nopember Institute of Technology (ITS), Surabaya, Indonesia. design concept of earthquake-resistant RC buildings [3-6].

The use of traditional transverse reinforcement has been well recognized to improve the strength and ductility of concrete members considerably [711]. Many efforts have been made to propose analytical model of the improved peak strength as well as the resulting axial stress-strain relationship of confined RC columns [12-19]. In addition, many studies have also been conducted to experimentally investigate the benefits of this confinement $[8,20]$. The scope of those studies has included vast variety of parameters. Concrete columns with circular, rectangular, and square sections have been covered. The specimens have been tested by axial as well as combined axial and bending load in monotonic and cyclic patterns. Both normal and high strength concrete have been addressed [11,21-23]. Some variables have been concluded to affect the confined concrete behavior, such as the plain concrete compressive strength, yield strength of confining reinforcement, volumetric ratio of confinement steel to concrete core, tie spacing and resulting tie configuration, and the amount of longitudinal steel around the core perimeter. The improved stress-strain relationship of confined concrete is characterized by the increment of compressive strength, flatter post-peak 
descending branch of the curve, and increment of ultimate compressive strain [24].

Besides the conventional confinement studies, many other studies have been conducted to investigate the advantages of external confinement methods [25-32]. Such external confinement approaches are essential to develop due to high demands on concrete columns retrofits. The contact behavior between concrete and external confinement elements, distribution of confining stress in 3D space, and the resulting failure mechanisms, which can be totally different to those of conventional stirrups, are promising areas for research in the external confinement approaches. Early studies of this approach have been proven to be successful in dealing with circular concrete columns. On the other hand, providing effective confining stress by external retrofit for rectangular and square columns is not a simple task. As in the case of internal confinement, the confining stress in the sectional shapes, is not uniform due to the stress concentration in the corners. Relatively fewer experimental and analytical studies are found to investigate this behavior [3335]. Recently, external confinement method to strengthen square RC columns by using hollowsquare steel section collars has been proposed and proven to be successful in improving the strength and ductility of the confined columns. To further investigate the effectiveness of such approach, an external confining method that utilizes light Lshaped steel section collars is studied for its capability as an alternative retrofit for square concrete columns.

\section{Experimental setup}

Nine columns specimens were built and tested under monotonic concentric compressive loading. Two control specimens, CS01 and CS03a, were built without any confinement and with internal stirrups, respectively, to conform the seismic requirement of the code [3]. The other seven were externally confined by a set of L-shaped steel section collars. Two of those seven specimens ( $\mathrm{S} 04 \mathrm{a}$ and $\mathrm{S} 04 \mathrm{~b}$ ) were initially confined with traditional internal stirrups. A set of L-shaped steel collars were then installed externally in order to observe the combined effect of both confinements. The observed behaviors can be used to confirm whether the proposed retrofitting method can be used to strengthen existing RC columns. The effect of external confinement alone was represented by Specimen S04. The rest of the specimens (S04, $\mathrm{S} 04 \mathrm{c}, \mathrm{S} 04 \mathrm{~d}, \mathrm{~S} 04 \mathrm{e}$, and S04f) are varied in terms of the application of the L-shaped steel section collars to study the extended use of the proposed approach. The strength and ductility enhancements of con- crete columns retrofitted by external L-shaped steel section collars were the main objective of the study. The sectional dimensions of the L-shaped steel section collars were $40 \mathrm{~mm} \times 40 \mathrm{~mm} \times 4 \mathrm{~mm}$ (L40.40.4). It will be abbreviated as L40 in the next sections of the paper. The external confinement was implemented to the column specimens by fastening the structural bolts at the four corners of a set of Lshaped steel section collar assemblage. The illustration of the assembled perspective view of a typical specimen is shown in Fig. 1.

The dimension of the specimen was $600 \mathrm{~mm}$ in height with square cross section $(200 \mathrm{~mm} \times 200$ $\mathrm{mm}$ ). Heavy confinement was installed in both 100 $\mathrm{mm}$ bottom and top ends of the specimens. Thus, no damage was expected in these non-test regions. Various configurations of external confinements were installed in the 400-mm mid-test regions, except for control specimens, CS01 and CS03a, with internal confinement only. In order to determine the gage length, a set of two rods was installed within the test regions protruding out from each face of the column specimens. Totally four LVDTs (Linear Variable Differential Transducers), one on each side of the specimens, were attached to the rods to measure the axial strain during the test.

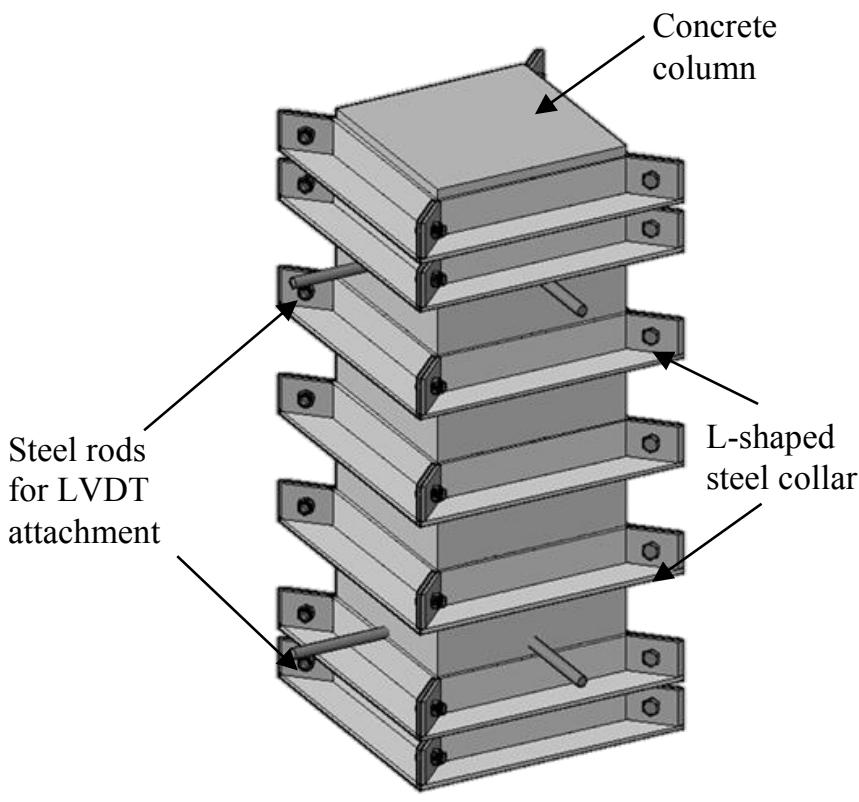

Fig. 1 - Assembled typical specimen

\section{Test specimens}

Illustrations of the specimens described previously are presented here. The longitudinal sections of the internal confinement can be seen in Fig. 2. The two control specimens, CS01 and CS03a, are shown in Fig. 2. Figure 2(a) represents specimens with no internal stirrups in the middle test region. To fullfil the code [3] requirement for seismic confinement, Specimen CS03a was built with D10- 
50 stirrups (Fig. 2(b)). The volumetric ratio was found to be 2.36 percent. The volumetric ratio is defined as the volume of the confinement steel with respect to the volume of column, obtained by multiplying the gross cross-sectional area and the spacing of confining elements. Figures $2(\mathrm{c})$ and (d) depict the internal stirrups of Specimens S04a and S04b, respectively. Specimen S04a was built such that the location of the internal and external confinements coincided with each other (volumetric ratio of 1.48 percent). Specimen S04b was modified from S04a such that the internal confinement could be placed exactly at the mid-spacing of the external L-shaped steel section collars. These two column specimens were intended to study and anticipate the influence of the two possible extreme locations of the external steel collars with regards to the location of the internal confinement in the existing columns. These two efforts are intended to consider the pos-

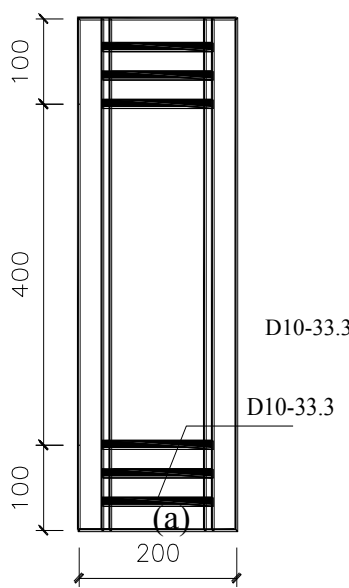

(a)

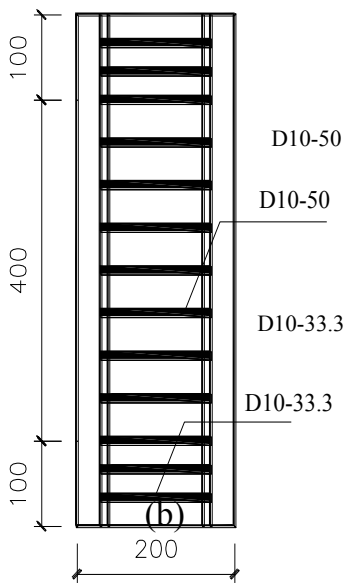

(b)

sible application of the proposed retrofitting method on existing $\mathrm{RC}$ columns in actual buildings.

The external confinement arrangements of the specimens are presented in Figs. 3 and 4. Specimens S04, S04a, and S04b are externally confined with L-shaped steel collars at $80 \mathrm{~mm}$ spacing without any web stiffeners or bolts (see Fig. 3(a)). The volumetric ratio of the external confinement is 9.60 percent. Figures 3(b) and (c) show the external confinement arrangements of Specimens $\mathrm{S} 04 \mathrm{c}$ and S04d, respectively. The steel collars are strengthened with additional one and two web stiffeners made from 6-mm thick steel plates for Specimens S04c and S04d, respectively. Figures 4(a) and (b) depict the external confinement arrangements of Specimens S04e and S04f, respectively. The contacts of steel collars to the concrete are strengthened with one and two additional bolts for Specimens S04e and S04f, respectively. The cross sections of the specimens are given

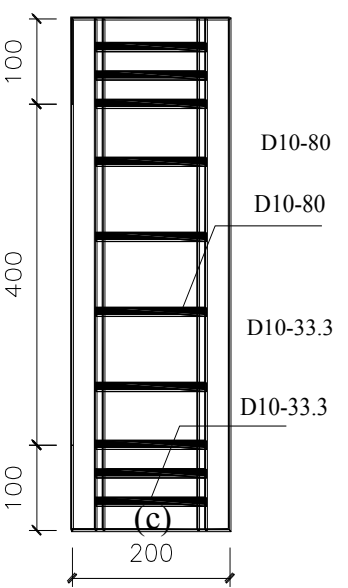

(c)

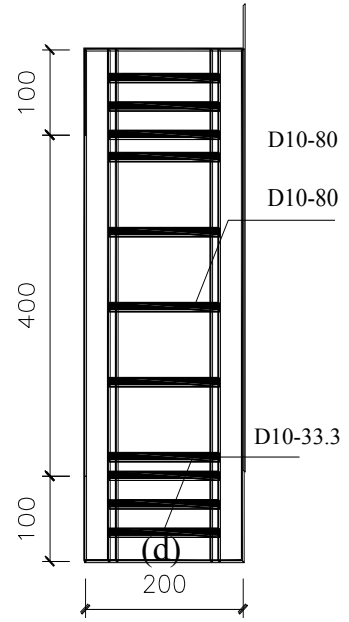

(d)

Fig. 2 - Longitudinal sections of internal confinement arrangements of specimens: (a) CS01, S04, S04c, S04d, S04e, S04f; (b) CS03a; (c) S04a; (d) S04f

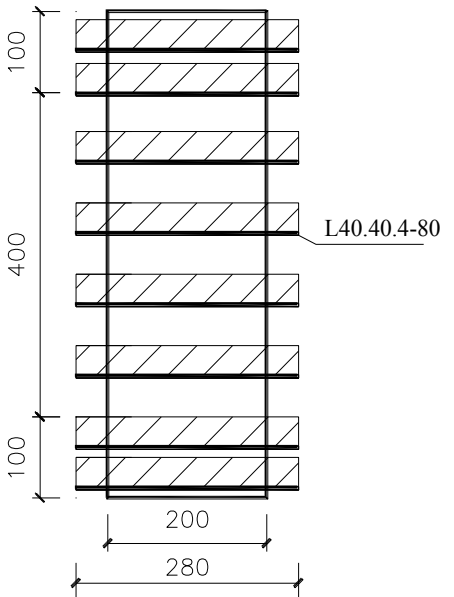

(a)

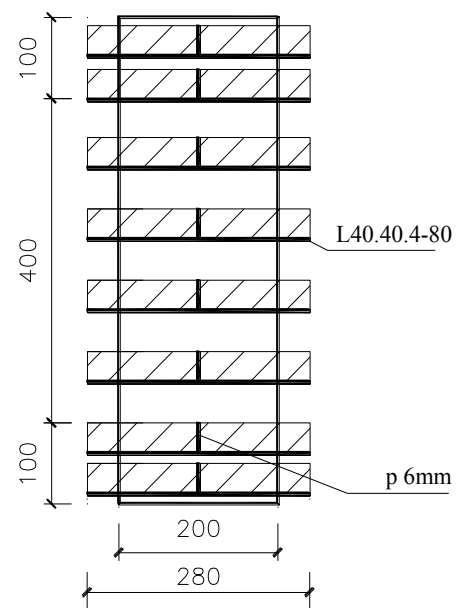

(b)

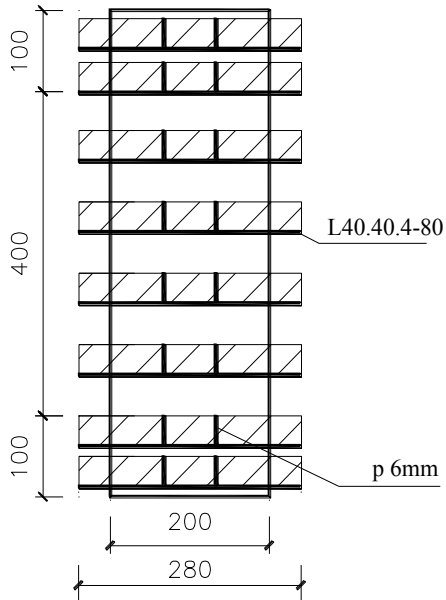

(c)

Fig. 3 - Elevation views of external confinement arrangements of specimens: (a) S04, S04a, S04b; (b) S04c; (c) S04d 


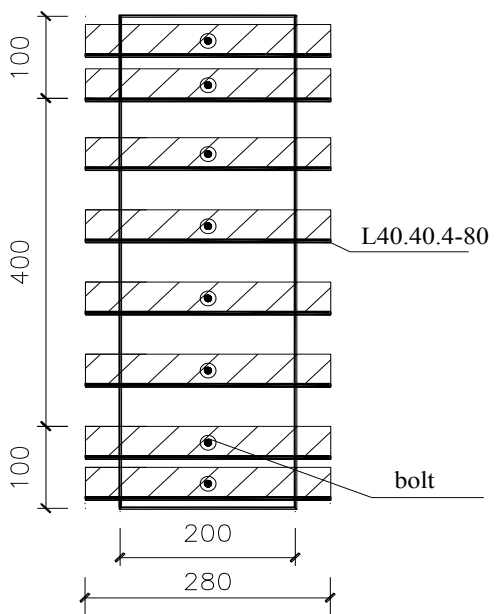

(a)

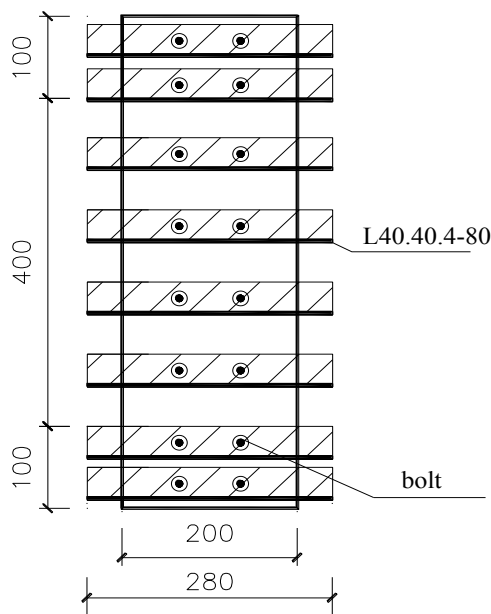

(b)

Fig. 4 - Elevation views of external confinement arrangements of specimens: (a) S04e; (b) S04f

in Figs. 5 and 6. Table 1 summarizes all the column specimens tested in the study.

Typical test setup of column specimens is shown in Fig. 7. The specimens are axially loaded with a displacement-controlled universal testing machine as shown in the figure. The machine is placed firmly on a strong floor to ensure no movement during the test. A Linear Variable Displacement Transducer (LVDT) is attached to each side of the column specimens for measuring the axial displacement during the test.

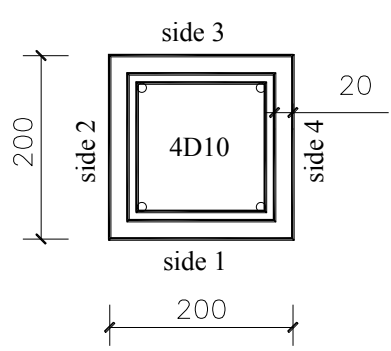

(a)

\section{Discussions on test results}

Standard concrete cylinders were made from the same mix proportion to obtain the mechanical properties of the concrete used in the specimens. The average compressive strength $\left(f_{c}^{\prime}\right)$ of the cylinders was $23.93 \mathrm{MPa}$ with the standard deviation of $2.01 \mathrm{MPa}$. It was also found from the standard tensile test that the average yield strength $\left(f_{y}\right)$ of the deformed bars was $317 \mathrm{MPa}$ with the standard deviation of 5.9 MPa. The average tensile strength $\left(f_{u}\right)$

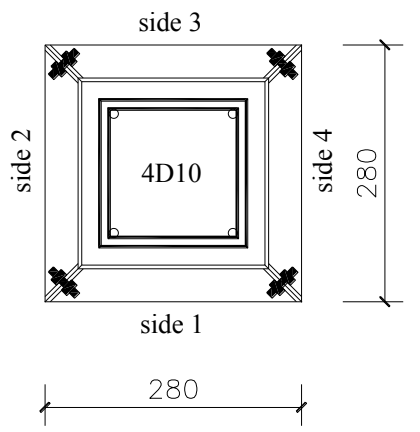

(b)

Fig. 5 - Cross sections of specimens: (a) CS01, CS03a; (b) S04, S04a, S04b

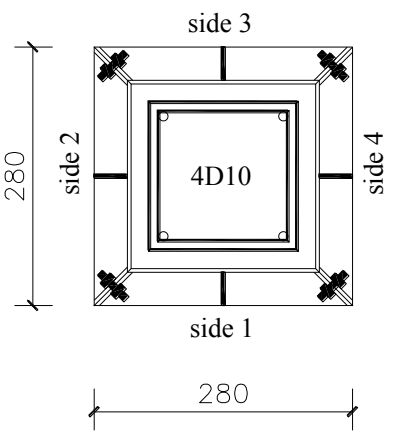

(a)

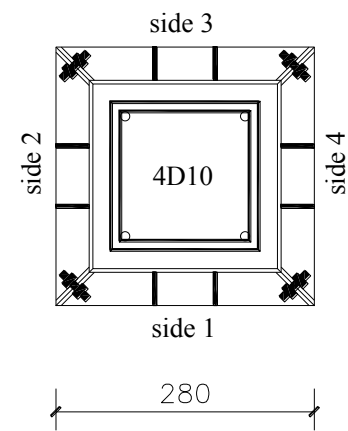

(b)

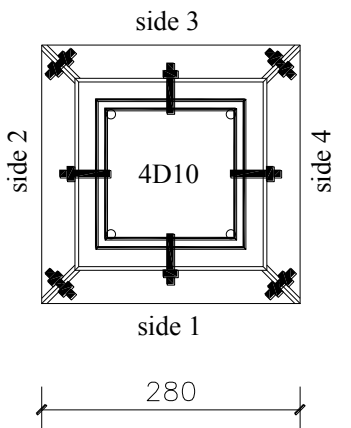

(c)

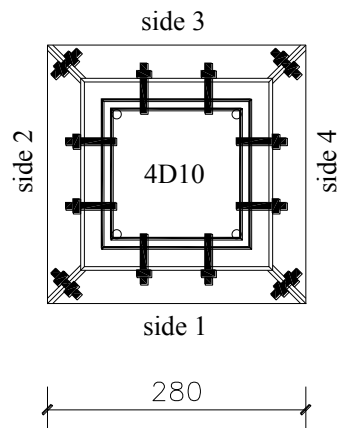

(d)

Fig. 6 - Cross sections of specimens: (a) S04c; (b) S04d; (c) S04e; (d) S04f 
Table 1 - Details of column specimens

\begin{tabular}{c|c|l|c}
\hline Column ID & Longitudinal bar & \multicolumn{1}{|c}{ Confining steel } & \multicolumn{1}{|c}{ Stiffener/bolt } \\
\hline CS01 & 4-D10 & None & None \\
\hline CS03a & 4-D10 & D10-50 (vol. ratio $=2.36 \%)$ & None \\
\hline S04 & 4-D10 & L40.40.4-80 (vol. ratio $=9.60 \%)$ & None \\
\hline S04a & 4-D10 & $\begin{array}{l}\text { L40.40.4-80 }(\text { vol. ratio }=9.60 \%) \\
\text { D10-80 }(\text { vol. ratio }=1.48 \%) \\
\text { External confinement is placed exactly at the same location as } \\
\text { internal confinement }\end{array}$ & None \\
& & $\begin{array}{l}\text { L40.40.4-80 }(\text { vol. ratio }=9.60 \%) \\
\text { D10-80 }(\text { vol. ratio }=1.48 \%)\end{array}$ & None \\
& & $\begin{array}{l}\text { External confinement is placed at mid-spacing of internal con- } \\
\text { finement }\end{array}$ & \\
\hline S04b & 4-D10 & L40.40.4-80 (vol. ratio $=9.60 \%)$ & One stiffener \\
\hline S04c & 4-D10 & L40.40.4-80 $($ vol. ratio $=9.60 \%)$ & Two stiffeners \\
\hline S04d & 4-D10 & L40.40.4-80 $($ vol. ratio $=9.60 \%)$ & One bolt \\
\hline S04e & 4-D10 & L40.40.4-80 $($ vol. ratio $=9.60 \%)$ & Two bolts \\
\hline S04f & 4-D10 & &
\end{tabular}

Note: All dimensions are in $\mathrm{mm}$

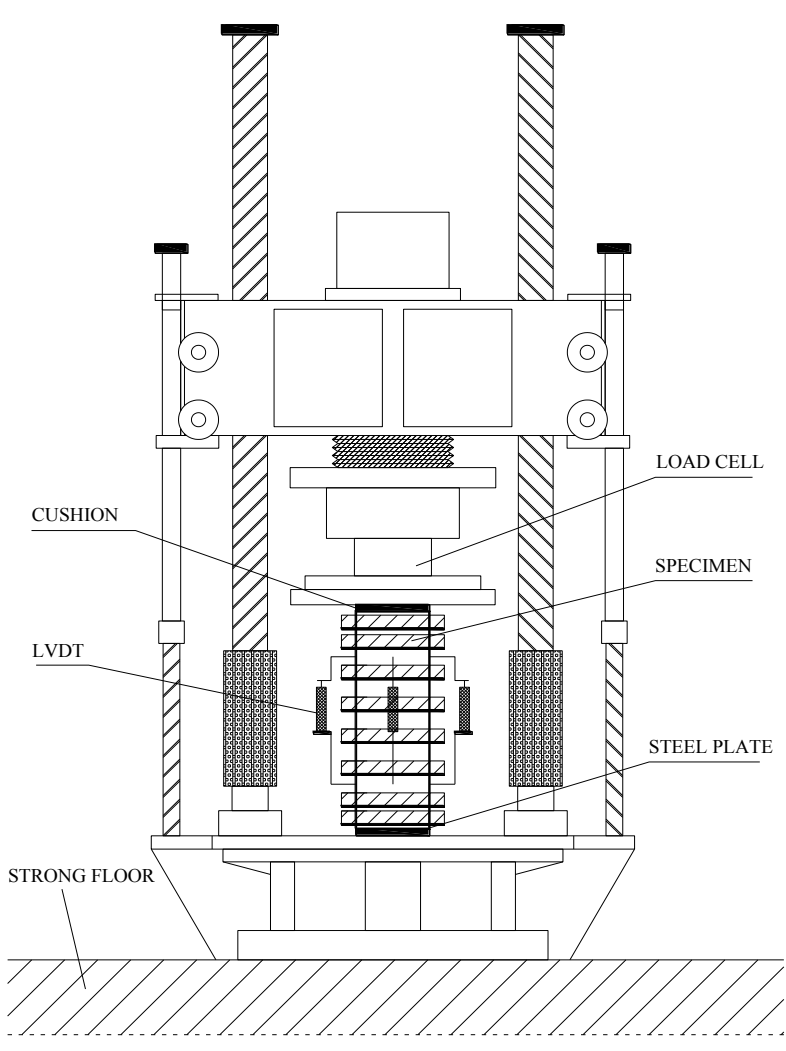

Fig. 7 - Typical test setup of column specimens

was $486 \mathrm{MPa}$ with the standard deviation of 3.8 $\mathrm{MPa}$. Three strip steel plates, cut from the Lshaped steel section, were also tested. The test indicated that the yield strength $\left(f_{y s c}\right)$ of the L-shaped steel section was $285 \mathrm{MPa}$.

The stresses of the specimens $\left(f_{c}\right)$ at any axial strains $\left(\varepsilon_{c}\right)$ obtained from the test were normalized by the peak strength $\left(f_{c 0}^{\prime}=19.07 \mathrm{MPa}\right)$ of unconfined Specimen CS01 in order to observe the strength gain due to confinements. The normalized axial stress-strain curves of the specimens can be seen in Fig. 8. The enhancements of strength $\left(f_{c} / f_{c 0}^{\prime}\right)$ and strain ductility $\left(\mu_{s}\right)$ are summarized in Table 2 . In the study, the strain ductility, $\mu_{s}$, is determined as the ratio of axial strain at 85 percent of peak stress in the descending (post-peak) branch $\left(\varepsilon_{85}\right)$ of the strain-strain curve of confined concrete with respect to the strain at the peak stress $\left(\varepsilon_{01}=\right.$ 0.23 percent) of unconfined concrete.

It can be seen that the unconfined Specimen CS01 showed non-ductile behavior. Seismicallyconfined Specimen CS03a indicated much better behavior in terms of strength and ductility enhancements. Specimen S04 did not perform as expected since one of the steel collars suffered a premature failure at its corner weld. The curve clearly indicated some strength gain, but relatively poor ductility.

Specimens S04c and S04d $\left(f_{c} / f_{c 0}^{\prime}=1.25\right.$ and 1.33 , respectively) only showed slight strength improvement over Specimen S04 $\left(f_{c} / f_{c 0}^{\prime}=1.21\right)$. However, they (Specimens S04c and S04d) performed much higher ductilities $\left(\mu_{s}=11.08\right.$ and 10.47 , respectively) compared to Specimen S04 $\left(\mu_{s}=3.46\right)$. It is important to note here that this ductility ratio does not represent the behavior of Specimen $\mathrm{S} 04$ as it is supposed to be. This is due to the premature failure of the collar's welds. It can be seen that the strengthening of the steel collars using web stiffeners was found to be ineffective. The confinement provided by the external steel collars primarily depends on the nominal axial and flexural capacities of the steel section [19]. Additional web stiffeners do not improve the capacities of the column, it only improves the local stability of steel 


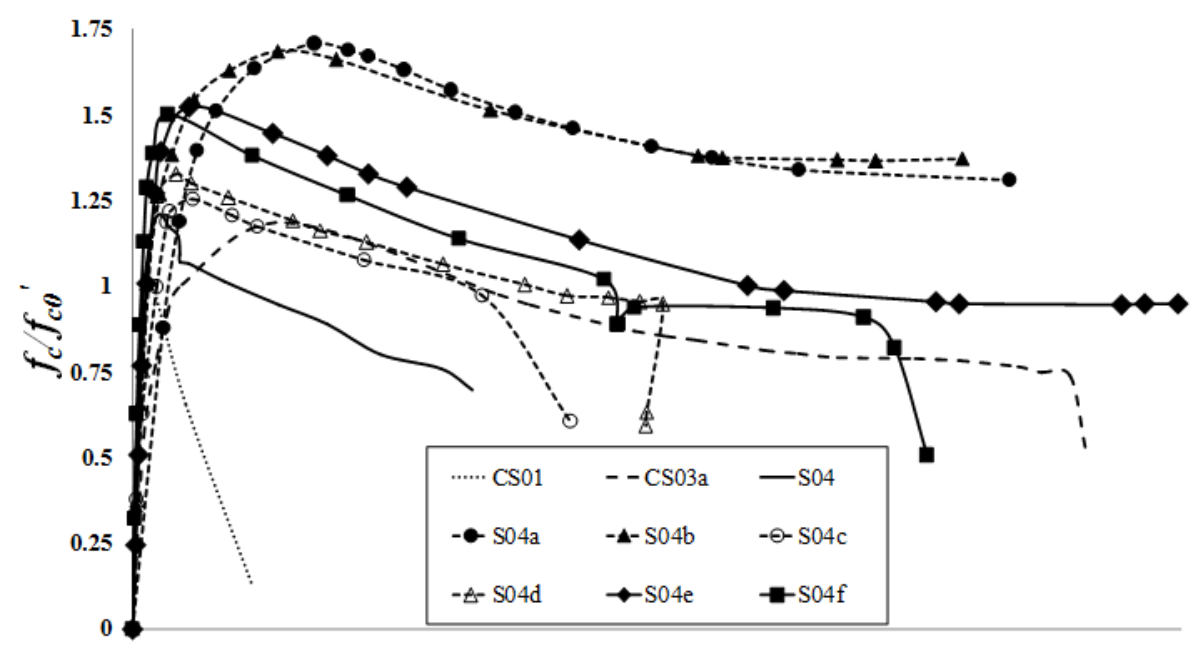

Strain $\varepsilon_{c}(\%)$

Fig. 8 - Normalized stress-strain curves

Table 2 - Enhancement of strengths and ductilities of the specimens

\begin{tabular}{c|c|c}
\hline Column ID & $f_{c} / f_{c 0}^{\prime}$ & $\mu_{s}$ \\
\hline CS01 & 1.00 & 1.63 \\
\hline CS03a & 1.19 & 15.55 \\
\hline S04 & 1.21 & 3.46 \\
\hline S04a & 1.71 & 21.21 \\
\hline S04b & 1.69 & 22.58 \\
\hline S04c & 1.25 & 11.08 \\
\hline S04d & 1.33 & 10.47 \\
\hline S04e & 1.52 & 12.38 \\
\hline S04f & 1.50 & 9.46 \\
\hline
\end{tabular}

section from buckling which is not significant since the length of steel collar is relatively short.

Specimens S04e and S04f performed much better than Specimens S04c and S04d. The enhancements of strength $\left(f_{c} / f_{c 0}^{\prime}\right)$ of Specimens S04e and $\mathrm{S} 04 \mathrm{f}$ are found to be 1.52 and 1.50 , respectively. However, in term of strain ductility, these specimens are comparable to Specimens S04c and S04d. Adding more bolts to better attach the steel collars is proven to be ineffective. In fact, Specimen S04f performed slightly inferior compared to Specimen S04e which used fewer bolts. This might be due to the fact that by using more bolts also means that more concrete damage could prematurely occur due to the drilling work.

Most importantly, Specimens S04a and S04b demonstrated the best results, which indicated that the proposed external confinement technique is very suitable for retrofitting purpose of existing RC columns. In Table 2, it can be clearly seen that both specimens showed much superior results than the remaining specimens. The strength of the speci- mens improved up to 70 percent over the control Specimens CS01. The strain ductilities were also recorded very high $\left(\mu_{s}=21.21\right.$ and 22.58 for Specimens S04a and S04b, respectively).

Brittle diagonal splitting was observed in Specimen CS01, while intact confined concrete core was observed in Specimen CS03a (Fig. 9). It can be seen in Fig. 10 that the third collar in the test region (numbered bottom-up) of Specimen S04 suffered a corner failure due to the bulging concrete. Figures 11 and 12 illustrate the damages of Specimens S04a and S04b, respectively. Specimen S04b with closer combined spacing of internal and external confining steels suffered less overall damages. Figures 13 and 14 exhibit the damages of Specimens S04c and S04d, respectively. This set of specimens gained the least strength and ductility enhancements as compared to the standard-collared Specimen S04. Figures 15 and 16 depict the damages of Specimens S04e and S04f, respectively. Some bolts were detached from the concrete due to the excessive concrete core damages during testing. 

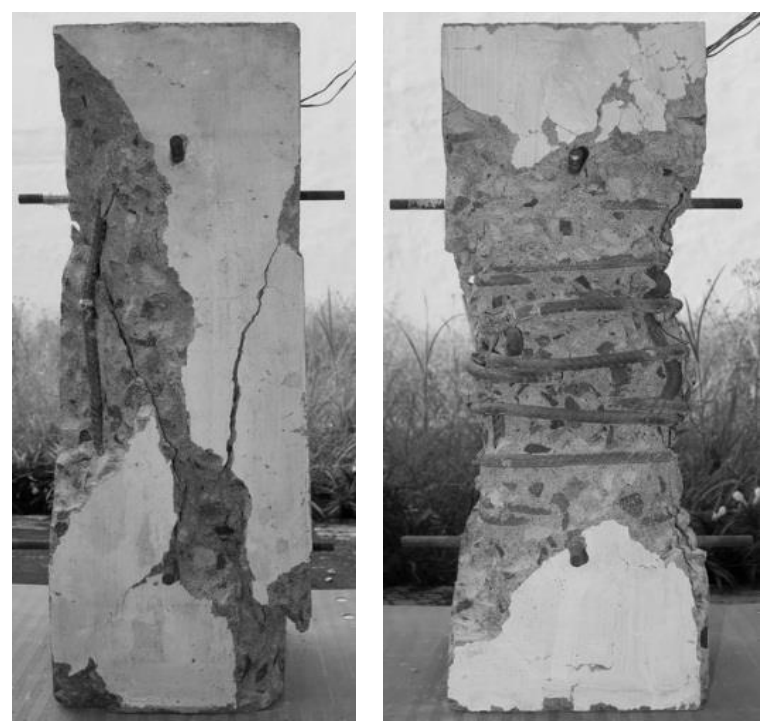

Fig. 9 - Specimens: (a) CS01; (b) CS03a, after completion of test

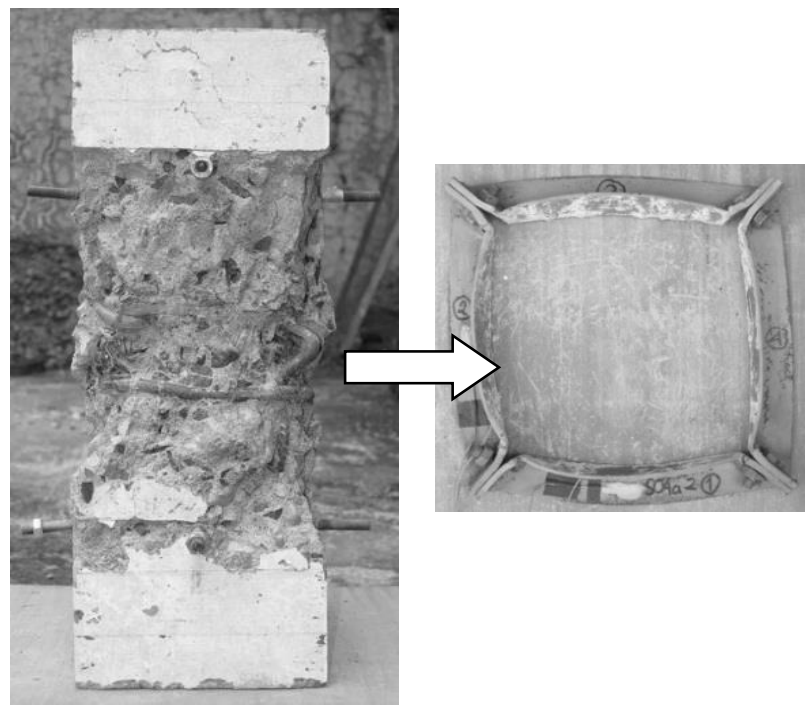

Fig. 11 - Specimen S04a after completion of test

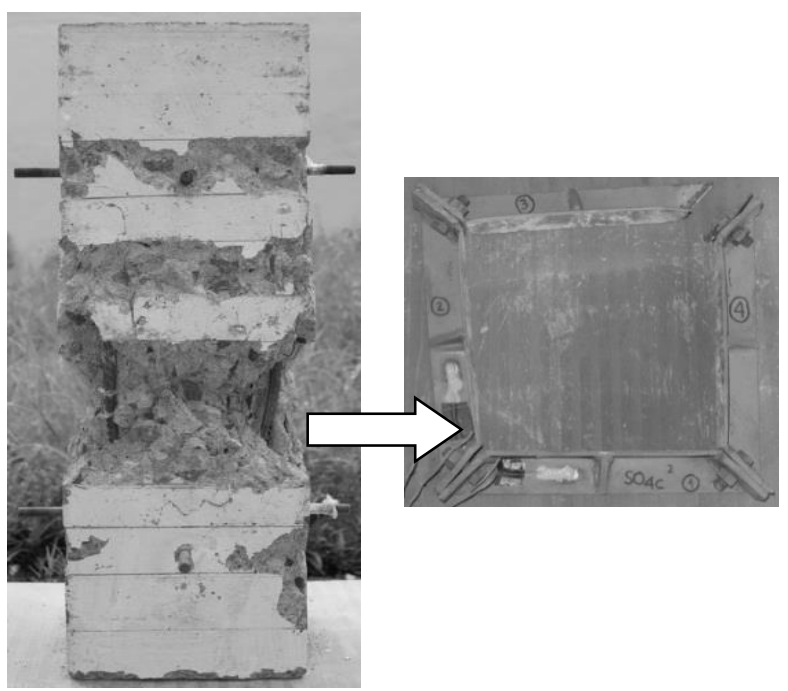

Fig. 13 - Specimen S04c after completion of test

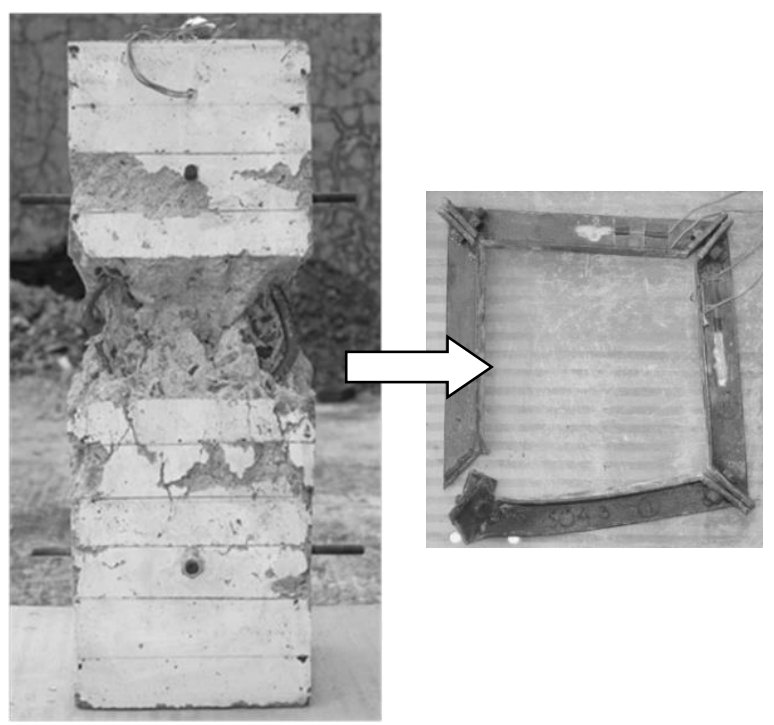

Fig. 10 - Specimen S04 after completion of test

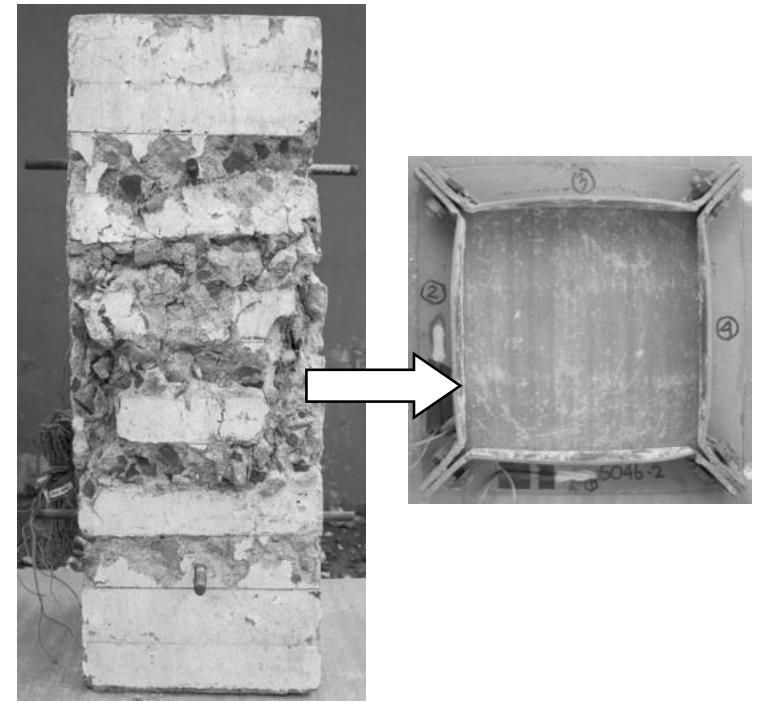

Fig. 12 - Specimen S04b after completion of test

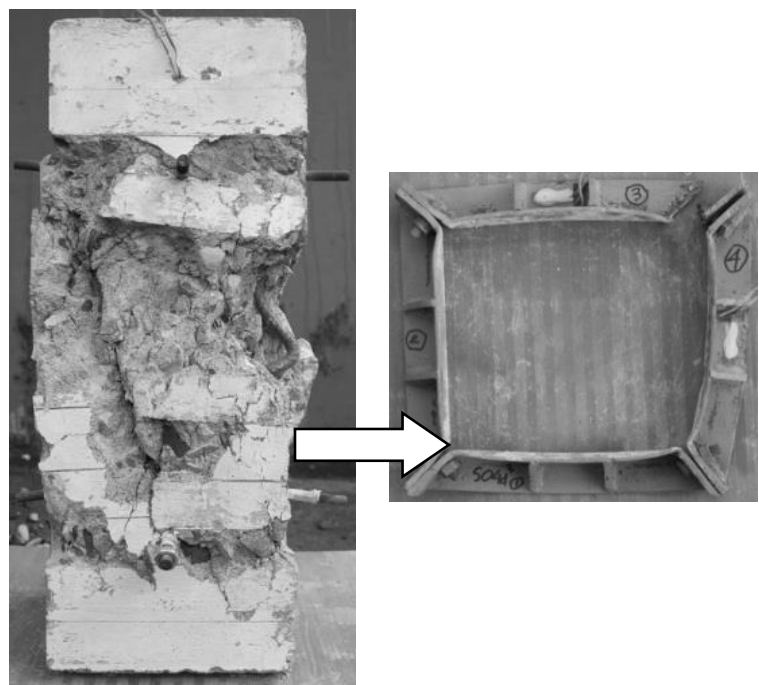

Fig. 14 - Specimen S04d after completion of test 


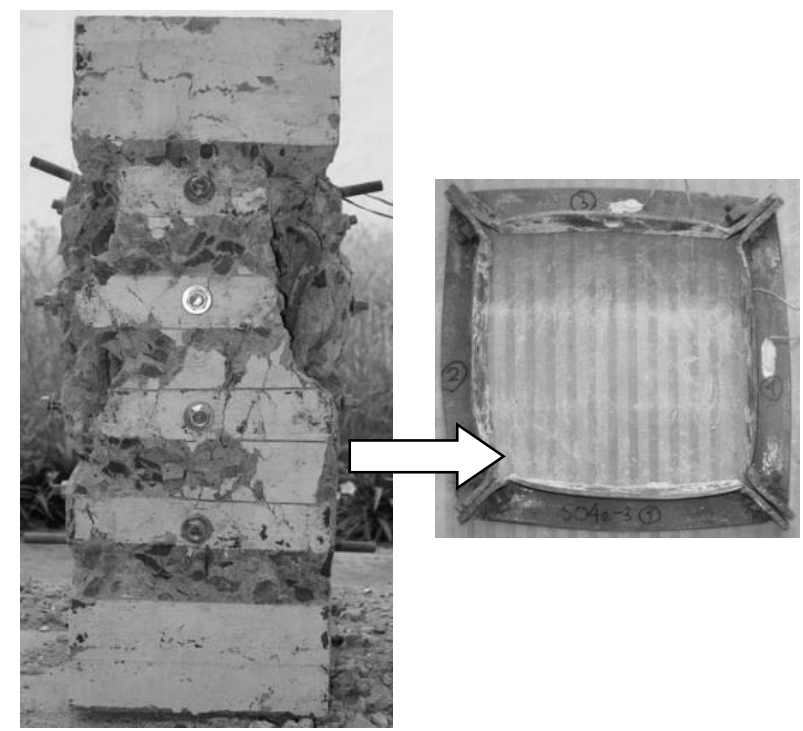

Fig. 15 - Specimen S04e after completion of test

\section{Conclusions}

An alternative of external confining technique for retrofitting square or rectangular concrete columns is presented. The technique has some promising advantages, such as better constructability (only minor cutting and welding processes are involved to prepare the steel collars), and higher applicability (the steel collars can be applied by only fastening the structural bolts at its four corners). Concentric static axial load tests have been conducted on nine column specimens to validate the reliability of the proposed technique. From the experimental program, some conclusions can be drawn as follows:

(1) The introduction of external confinement using L-shaped steel collars has successfully enhanced both strength and ductility of RC columns. The compressive strength gain was observed as high as 21 percent for the standardcollared Specimen S04 compared with that without confinement. However, the ductility enhancement of Specimen S04 is not as good as expected due to the premature failure of collar's welds.

(2) The control Specimen CS03a with the standard internal confinement required by the seismic provision showed 19 percent strength gain. All the L-shaped steel-collared specimens (except Specimen S04) showed higher strength gain than Specimen CS03a. Specimens S04c and S04d (steel collars with web stiffeners) showed the least strength improvement. Specimens S04e and S04f (steel collars with bolts) showed better strength improvement over Specimens S04c and S04d. Specimens with the combination of both internal stirrups and external steel collars (S04a and S04b) showed the

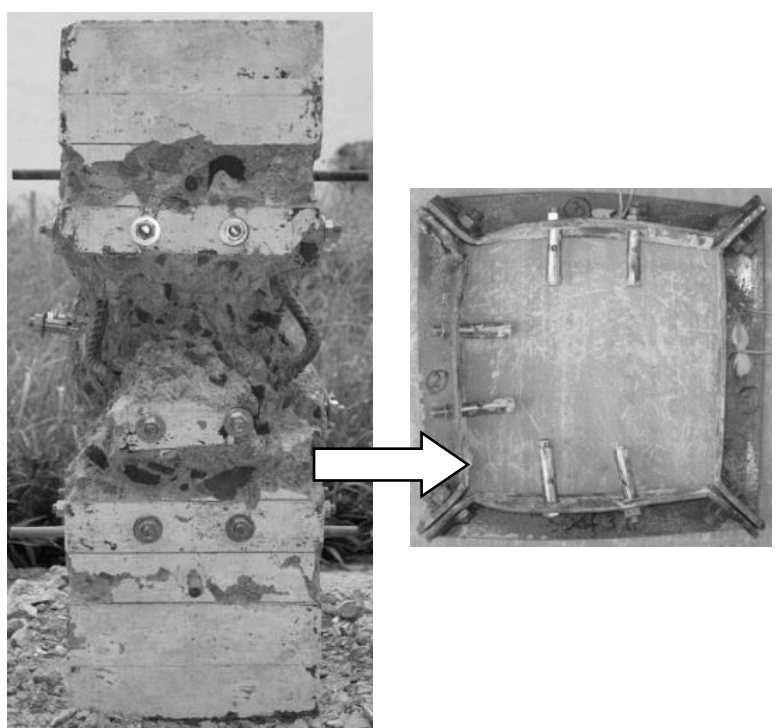

Fig. 16 - Specimen S04f after completion of test

highest strength improvement than the remaining specimens.

(3) In terms of ductility, control Specimen CS03a gave the strain ductility ratio of 15.55 . Specimens retrofitted only with L-shaped steel collars (S04c, S04d, S04e, and S04f) indicated slightly less ductility than Specimen CS03a despite their excellent strength gains. Only Specimens S04a and S04b performed better ductility than Specimen CS03a.

(4) The retrofit of existing RC columns simulated by Specimens S04a and S04b has demonstrated excellent results. These set of specimens exhibited the best performance with strength gain found as high as 71 percent. Both tests were terminated due to the limitation of LVDT's capacity. Both specimens can still maintain at least 78 percent of their peak load carrying capacities

\section{Acknowledgements}

The first phase of the multiyear research project, that involved an experimental work, has been conducted in the Structural Laboratory at Center of Research and Settlement Development, Ministry of Public Works, Bandung, Indonesia. The authors express their sincere gratitude for all the support received.

\section{References}

1. Tavio; and Teng, S. (2004) "Effective Torsional Rigidity of Reinforced Concrete Members," ACI Structural Journal, 101(2), pp. 252-260.

2. Tavio (2006) "Interactive Mechanical Model for Shear Strength of Deep Beams. Discussion," Journal of Structural Engineering, ASCE, 132(5), pp. 826-829.

3. SNI-2847 Committee (2013) Structural Concrete Requirements for Buildings (SNI 2847:2013), National Standardization Board (BSN), Jakarta, Indo- 
nesia, $264 \mathrm{pp}$.

4. Teng, S.; and Tavio (2003) "Deflections of Flat Plate Floors with Irregular Column Layout," Deflection Control for the Future, ACI SP-210, American Concrete Institute (ACI), pp. 37-63.

5. Tavio (2008) Building Code Requirements for Structural Concrete (ACI 318-08) and Commentary (ACI 318R-08), Discussion and Closure, Concrete International, American Concrete Institute (ACI), 30(4), pp. 1-171.

6. SNI-1726 Committee (2012) Seismic-Resistant Design Code for Buildings (SNI 1726:2012), National Standardization Board (BSN), Jakarta, Indonesia, $138 \mathrm{pp}$.

7. Sheikh, S.A. (1982) "A Comparative Study on Confinement Models,” ACI Journal, 79(4), pp. 296-306.

8. Mander, J.B.; Priestley, M.J.N.; and Park, R. (1988) "Theoretical Stress-Strain Model for Confined Concrete," Journal of Structural Engineering, ASCE, 114(8), pp. 1824-1826.

9. Mander, J.B.; Priestley, M.J.N.; and Park, R. (1988) "Observed Stress-Strain Behavior of Confined Concrete," Journal of Structural Engineering, ASCE, 114(8), pp. 1827-1849.

10. Saatcioglu, M.; and Razvi, S.R. (1992) "Strength and Ductility of Confined Concrete," Journal of Structural Engineering, ASCE, 118(6), pp. 15901607.

11. Hoshikusuma, J.; Kawashima, K.; Nagaya, K.; and Taylor, A.W. (1997) "Stress-Strain Model for Confined Reinforced Concrete in Bridge Piers," Journal of Structural Engineering, ASCE, 123(5), pp. 624633.

12. Rasvi, S.; and Saatcioglu, M. (1999) "Confinement Model for High Strength Concrete," Journal of Structural Engineering, ASCE, 125(3), pp. 281-289.

13. Kusuma, B.; and Tavio (2008) "Unified StressStrain Model for Confined Columns of Any Concrete and Steel Strengths," Proceedings of the $1^{\text {st }}$ International Conference on Earthquake Engineering and Disaster Mitigation (ICEEDM-I), Jakarta, Indonesia.

14. Tavio; and Kusuma, B. (2009) "Stress-Strain Model for High-Strength Concrete Confined by Welded Wire Fabric," Discussion, Journal of Materials in Civil Engineering, ASCE, 21(1), pp. 40-45.

15. Tavio; Wimbadi, I.; Negara, A.K.; and Tirtajaya, R. (2009) "Effects of Confinement on Interaction Diagrams of Square Reinforced Concrete Columns," Civil Engineering Dimension, 11(2), pp. 78-88.

16. Tavio; and Tata, A. (2008) "Stress-Strain Relation and Nonlinear Behavior of Circular Confined Reinforced Concrete Columns," Journal of Communication Media in Civil Engineering, 16(3), pp. 255-268.

17. Tavio; and Tata, A. (2009) "Predicting Nonlinear Behavior and Stress-Strain Relationship of Rectangular Confined Concrete Columns with ANSYS," Civil Engineering Dimension, 11(1), pp. 23-31.

18. Tavio; Suprobo, P.; and Kusuma, B. (2011) "Investigation of Stress-Strain Models for Confinement of Concrete by Welded Wire Fabric," Journal of Procedia Engineering, 14, pp. 2031-2038.

19. Pudjisuryadi, P.; and Tavio (2013) "Compressive
Strength Prediction of Square Concrete Columns Retrofitted with External Steel Collars," Civil Engineering Dimension, 15(1), pp. 18-24.

20. Tavio; Kusuma, B.; and Suprobo, P. (2012) "Experimental Behavior of Concrete Columns Confined by Welded Wire Fabric as Transverse Reinforcement under Axial Compression," ACI Structural Journal, 109(3), pp. 339-348.

21. Tavio; Suprobo, P.; and Kusuma, B. (2007) "Effects of Grid Configuration on the Strength and Ductility of HSC Columns Confined with Welded Wire Fabric under Axial Loading," Proceedings of the 1st International Conference on Modern, Construction and Maintenance of Structures, Hanoi, Vietnam.

22. Tavio; Budiantara, I.N.; and Kusuma, B. (2008) "Spline Nonparametric Regression Analysis of Stress-Strain Curve of Confined Concrete," Civil Engineering Dimension, 10(1), pp. 14-27.

23. Tavio; Suprobo, P.; and Kusuma, B. (2008) "Strength and Ductility Enhancement of Reinforced HSC Columns Confined with High-Strength Transverse Steel," Proceedings of the Eleventh East Asia-Pacific Conference on Structural Engineering \& Construction (EASEC-11), Taipei, Taiwan.

24. Tavio; Suprobo, P.; and Kusuma, B. (2008) "Ductility of Confined Reinforced Concrete Columns with Welded Reinforcement Grids," Proceedings of the International Conference Excellence in Concrete Construction through Innovation, London, UK.

25. Chai, Y.H.; Priestley, M.J.N.; and Seible, F. (1994) "Analytical Model for Steel-Jacketed RC Circular Bridge Columns," Journal of Structural Engineering, ASCE, 120(8), pp. 2358-2376.

26. Saafi, M.; Toutanji, H.A.; and Li, Z. (1999) "Behavior of Concrete Columns Confined with FiberReinforced Polymer Tubes," ACI Material Journal, 96(4), pp. 500-509.

27. Fam, A.Z.; and Rizkalla, S.H. (2001) "Confinement Model for Axially Loaded Concrete Confined by Circular Fiber-Reinforced Polymer Tubes," ACI Structural Journal, 98(4), pp. 541-461.

28. Carey, S.A.; and Harries, K.A. (2005) “Axial Behavior and Modeling of Confined Small-, Medium-, and Large-Scale Circular Sections with Carbon Fiber-Reinforced Polymer Jackets," ACI Structural Journal, 102(4), pp. 596-604.

29. Pudjisuryadi, P.; Tavio; and Suprobo, P. (2011) "Transverse Stress Distribution in Concrete Columns Externally Confined by Steel Angle Collars," Proceedings of the $2^{\text {nd }}$ International Conference on Earthquake Engineering and Disaster Mitigation (ICEEDM-II), Surabaya, Indonesia.

30. Pudjisuryadi, P.; Tavio; and Suprobo, P. (2014) "Analytical Confining Model of Square Reinforced Concrete Columns using External Steel Collars," International Journal of ICT-aided Architecture and Civil Engineering, 1(1), pp. 1-18.

31. Achmad, K.; Suhardjono, A.; and Tavio (2013) "Experimental Behavior of Seismic-Resistant Structural RC Columns Retrofitted with CFRP as External Confinement," Journal of Integrated Technology, 1(1), pp. 30-36. 
32. Tavio; Achmad, K.; Parmo; and Sulistiawan, A. (2013) "Strength and Ductility of RC Columns Retrofitted by FRP under Cyclic Loading," Proceedings of the 4th International Conference on Applied Technology, Science, and Arts (APTECS-IV), Surabaya, Indonesia.

33. Xiao, Y.; and Wu, H. (2003) "Retrofit of Reinforced Concrete Columns using Partially Stiffened Steel Jackets," Journal of Structural Engineering, ASCE, 129(6), pp. 725-732.

34. Hussain, M.A.; and Driver, R.G. (2005) "Experimental Investigation of External Confinement of Reinforced Concrete Columns by Hollow Structural Section Collars," ACI Structural Journal, 102(2), pp. 242-251.

35. Lee, C.S.; Hegemier, G.A.; and Phillippim D.J. (2010) "Analytical Model for Fiber-Reinforced Polymer-Jacketed Square Concrete Columns in Axial Compression," ACI Structural Journal, 107(2), pp. 208-217. 